\title{
Effects of Serum Cystatin C Levels on Increased Systolic and Diastolic Blood Pressure in the Elderly With Normal Renal Function
}

\author{
Erlina Marfianti ${ }^{1, *}$ Auliya Nisa ${ }^{2}$
}

\author{
${ }^{1}$ Internal Medicine Department, Faculty of Medicine, Islamic University of Indonesia, Yogyakarta, Indonesia \\ ${ }^{2}$ Faculty of Medicine, Islamic University of Indonesia, Yogyakarta, Indonesia \\ ${ }^{*}$ Corresponding author. Email: erlina.marfianti@uii.ac.id
}

\begin{abstract}
Increased systolic and diastolic blood pressure is a result of the process of blood vessel degeneration that often occurs in the elderly. A number of previous studies have shown that cystatin $\mathrm{C}$ is a strong predictor of cardiovascular and mortality risk in elderly individuals though the mechanism remains unclear. Cystatin $\mathrm{C}$ also increases in individuals with decreased renal function. The objective of this study was to determine the effects of serum cystatin C levels on the systolic and diastolic blood pressure of the elderly with normal renal function. This was an analytical observational study with a cross-sectional design. The subjects of this study were both men and women aged $\geq 60$ years old without renal function impairment. The subjects underwent systolic and diastolic blood pressure measurements, and their venous blood was taken to check the levels of serum cystatin C. The data were analyzed using a fischer exact test. Involving 40 elderly subjects, this study found that the mean systolic blood pressure was $147.750 \pm 23.258 \mathrm{mmHg}$, and the mean diastolic blood pressure was $88.250 \pm 11.353 \mathrm{mmHg}$ while the mean level of serum cystatin $\mathrm{C}$ was $1.106 \pm 0.006 \mathrm{mg} / \mathrm{l}$. The statistical analysis showed a significant relationship between the levels of serum cystatin $\mathrm{C}$ and the systolic $(\mathrm{p}=0.030, \mathrm{RR}=1.431,95 \% \mathrm{CI}: 0.983-2.275)$ and diastolic blood pressure $(\mathrm{p}=0.000, \mathrm{RR}=1.290,95 \% \mathrm{CI}$ : 0.515 12.076). In conclusion, elevated serum cystatin $\mathrm{C}$ levels were associated with increased systolic and diastolic blood pressure in elderly people with normal renal function.
\end{abstract}

Keywords: Cystatin C, Systolic blood pressure, Diastolic blood pressure, Elderly, Normal renal function

\section{INTRODUCTION}

Globally, the number of elderly population in the world is on the rise, resulting in increased chronic and multipathological degenerative diseases that require a long-term high-cost treatment [1]. Degenerative changes may appear with age, manifested in such diseases as high blood pressure, heart disease, diabetes mellitus, renal disease, and others [2].

Indonesia basic health research (RISKESDAS) 2013 reported that the prevalence of hypertension in Indonesia was 26.5 percent with the highest percentage found in Bangka Belitung (30.9\%). Prosentase besar lainnya ditemukan di kota South Kalimantan (30.8\%), East Kalimantan (29.6\%), and West Java (29.4\%). The highest prevalence of elderly population is in Yogyakarta (13.81\%), this causes chronic diseases in the elderly such as necessary hypertension, to become a health problem. Such prevalence increased with age and tended to be higher in women than in men. In addition, this prevalence was also found higher in urban area than in rural area [1][3]. The data from the National Health and Nutrition Examination Survey (NHNES) III indicated that $65 \%$ of uncontrolled hypertension patients had ISH (Isolated Systolic Hypertension), and $80 \%$ of them were elderly people [4].
Hypertension in individuals can come from a combination of systolic and diastolic hypertension, or it can manifest itself as only systolic hypertension or known as isolated systolic hypertension. Isolated systolic hypertension is defined as increased systolic blood pressure with normal diastolic blood pressure (under $90 \mathrm{mmHg}$ ) due to an increase in both cardiac output and aortic stiffness [5].

Hypertension is a risk factor for vascular damage, endstage kidney disease and heart failure, the incidence of which continues to rise. The increase in either systolic or diastolic pressure in the blood vessels will increase the risk of cardiovascular morbidity and mortality. Changes in the blood vessels of elderly people are characterized by the thickening of tunica intima as a result of aging process. The changes lead to reduced blood vessel elasticity, resulting in increased blood pressure, particularly the systolic blood pressure [6].

A previous study showed that an increase in serum cystatin $\mathrm{C}$ levels is correlated with mortality risk as some types of cardiovascular diseases (including hypertension) and aging are related to increased cystatin C. Serum cystatin $\mathrm{C}$ can also become a risk factor for cardiovascular damage and death, not only used as a marker to assess renal function [7]. Cystatin $\mathrm{C}$ is a protein weighing $13.3 \mathrm{kD}$ produced by all cells that have a nucleus. It is a cysteine protease 
inhibitor filtered by the glomerulus without any restrictions but not secreted by the renal tubules. Cystatin $\mathrm{C}$ is produced at a constant rate with renal elimination only from the glomerular filtration. In addition, this protein is not affected by sex, age, or muscle mass [8]. A study showed that Cystatin $\mathrm{C}$ as a marker of renal impairment and a predictor of cardiovascular morbidity and mortality, is also closely related to elevated left ventricular mass. It can be concluded that cystatin $\mathrm{C}$ is a marker of cardiac hypertrophy in hypertensive patients. [9].

Each increase in cystatin C levels of $15 \mathrm{nmol} / \mathrm{L}(0.2$ $\mathrm{mg} / \mathrm{L}$ ) can lead to $15 \%$ increase in the risk of hypertension incidence. The relationship between the levels of cystatin $\mathrm{C}$ and hypertension incidence remains the same in patients with eGFR $\geq 90 \mathrm{~mL} / \mathrm{s}$ per $1.73 \mathrm{~m}^{2}$. Cystatin $\mathrm{C}$ can also be used as a risk marker of cardiovascular damage, heart disease, and death. Studies in a number of patients with essential hypertension showed that serum cystatin $\mathrm{C}$ is a sensitive marker to assess the severity of cardiovascular damage, left ventricular hypertrophy, and carotid artery thickening [10][11]. An epidemiological study suggested that cystatin $\mathrm{C}$ is more reliable compared to creatinine for predicting cardiovascular morbidity and mortality in the elderly people and population not suffering from a chronic renal disease. Aside from the role as a marker to assess renal function, cystatin $\mathrm{C}$ is expected to exhibit another correlation with cardiovascular risk factors, thus allowing it to be used as a marker of cardiac damage in patients with hypertension, but the clear mechanism between the two has yet to be fully recognized [12].

Serum cystatin $\mathrm{C}$ is a strong predictor of the risk of cardiovascular disease and death in elderly people. This present study therefore aims to determine the effects of serum cystatin $\mathrm{C}$ levels on the systolic and diastolic blood pressure in elderly population with normal renal function.

\section{METHODS}

This was observational analytic study with cross sectional method design. Population of this study was participants of elderly at Integrated Health Service Post (Posyandu) in Kotagede Yogyakarta aged $\geqslant 60$ years old. The minimum sample needed according to the calculation was 40 samples collected using consecutive sampling method. Inclusive criteria in this study were patients aged $\geqslant 60$ years old, without impaired renal function, determined by Glomerular Filtration Rate (GFR) > $60 / \mathrm{mL} / \mathrm{s} / 1,73 \mathrm{~m} 2$. The exclusion criteria were elderly with comorbid disease heart failure and acute infectious diseases. This study was started by filling anamnesis form to find characteristics of subjects and then it was followed by the measurement of systolic and diastolic blood pressure as well as blood sampling to measure the level of serum cystatin C.

The data for age was reported by year. Systolic blood pressure was determined as high if the systolic blood pressure $\geqslant 140 \mathrm{~mm} \mathrm{Hg}$, and diastolic blood pressure was determined as high if the diastolic blood pressure $\geqslant 90 \mathrm{~mm}$ $\mathrm{Hg}$ in at least 2 measurements. The level of serum cystatin $\mathrm{C}$ was measured by taking blood sample from study subjects and then it was followed by the measurement in laboratory. Serum cystatin $\mathrm{C}$ was measured using nephelometry and it was reported in $\mathrm{m} / \mathrm{L}$. The level of normal cystatin in the body of Asian people was under $0.9 \mathrm{mg} / \mathrm{L}$. Therefore, when the level of cystatin was above $0.9 \mathrm{mg} / \mathrm{L}$, it can be considered as high, and when the level of cystatin was less or same with 0.9 , it can be considered as normal [11]. Blood sampling for GFR measurement was performed simultaneously with blood sampling for the measurement of the level of cystatin $\mathrm{C}$. The data obtained from the study results were analyzed using fischer exact test.

This study kept the confidentiality of the patients, and performed all procedures according to study ethic. This study obtained approval from ethical review committee for biomedical study involving human subjects and informed written consent was taken from subjects.

\section{RESULTS}

There were 40 subjects completing the anamnesis forms and having their blood pressure measured. The characteristics of the subjects are shown in Table 1. The age of the subjects in this study ranged from 60 years to 89 years dominated by 27 male participants $(67.5 \%)$ with the rest comprising 13 female subjects $(32.5 \%)$. The mean glomerular filtration rate was $75.909 \pm 17.452 \mathrm{~mL} / \mathrm{s} / 1.73 \mathrm{~m}^{2}$, and the mean cystatin C level was $1.106 \pm 0.006 \mathrm{mg} / \mathrm{L}$. The variables of age, systolic blood pressure, diastolic blood pressure, glomerular filtration rate, and cystatin $\mathrm{C}$ levels were normally distributed. 
Table 1. Baseline Characteristics of the Elderly with Normal Renal Function

\begin{tabular}{|c|c|c|c|c|}
\hline$\overline{\text { Variable }}$ & Min & $\operatorname{Max}$ & Mean \pm SD & $\mathrm{P} * *$ \\
\hline Age (year) & 60 & 89 & $65.95 \pm 8.108$ & $\mathrm{p}>0.05$ \\
\hline $\begin{array}{l}\text { Gender: } \\
\text { Male }(\%) \\
\text { Female }(\%)\end{array}$ & & & $\begin{array}{l}27(67.5 \%) \\
13(32.5 \%)\end{array}$ & \\
\hline $\begin{array}{l}\text { Blood Pressure }(\mathrm{mmHg}) \\
\text { Systolic } \\
\text { Diastolic }\end{array}$ & $\begin{array}{c}110 \\
70\end{array}$ & $\begin{array}{l}240 \\
120\end{array}$ & $\begin{array}{c}147.750 \pm 23.258 \\
88.250 \pm 11.353\end{array}$ & $\mathrm{p}>0.05$ \\
\hline *GFR (mL/s/1.73m²) & 68.10 & 105.70 & $75.909 \pm 17.452$ & $\mathrm{p}>0.05$ \\
\hline Level of Cystatin C (mg/L) & 0.46 & 4.54 & $1.106 \pm 0.006$ & $p>0.05$ \\
\hline
\end{tabular}

In this study, the levels of serum cystatin $\mathrm{C}$ were grouped into high level $(>0.9 \mathrm{mg} / \mathrm{L})$ and normal level $(\leq 0.9 \mathrm{mg} / \mathrm{L})$ while the systolic and diastolic blood pressure levels were also divided into high $(\geq 140)$ and normal systolic blood pressure $(<140)$. A statistical test was performed to identify the relationship between the serum cystatin $C$ levels and the systolic and diastolic blood pressure. Based on both data, an analysis was performed using the fischer exact test. The analysis results of the relationship between the levels of serum cystatin $\mathrm{C}$ and the systolic and diastolic blood pressure are presented in Table 2 and Table 3.

Table 2. Relationship Between Systolic Blood Pressure with Serum Cystatin C Levels

\begin{tabular}{|c|c|c|c|}
\hline Variable & $\begin{array}{l}\text { High systolic } \\
\text { blood } \\
\text { pressure } \\
(\geq 140)\end{array}$ & $\begin{array}{l}\text { Normal } \\
\text { systolic blood } \\
\text { pressure } \\
(<140)\end{array}$ & $\mathbf{P}^{*}$ \\
\hline $\begin{array}{l}\text { High Cystatin } \\
C(>0.9 \mathrm{mg} / \mathrm{L})\end{array}$ & 25 & 4 & \multirow[t]{2}{*}{$\begin{array}{l}\mathrm{P}= \\
0.030\end{array}$} \\
\hline $\begin{array}{l}\text { Normal } \\
\text { Cystatin C } \\
(\leq 0.9 \mathrm{mg} / \mathrm{L})\end{array}$ & 4 & 7 & \\
\hline
\end{tabular}

Table 3. Relationship Between Diastolic Blood Pressure with Serum Cystatin C Levels

\begin{tabular}{|c|c|c|c|}
\hline Variable & $\begin{array}{l}\text { High } \\
\text { Diastolic } \\
\text { blood } \\
\text { pressure } \\
(\geq 90)\end{array}$ & $\begin{array}{l}\text { Normal } \\
\text { systolic blood } \\
\text { pressure } \\
(<90)\end{array}$ & $\mathbf{P} *$ \\
\hline $\begin{array}{l}\text { High Cystatin } \\
\text { C (>0.9 mg/L) }\end{array}$ & 20 & 9 & $\begin{array}{l}P= \\
0.000\end{array}$ \\
\hline $\begin{array}{l}\text { Normal } \\
\text { Cystatin C } \\
(\leq 0.9 \mathrm{mg} / \mathrm{L})\end{array}$ & 4 & 7 & \\
\hline
\end{tabular}

The analysis using the fischer exact test found a relationship between the levels of serum cystatin $\mathrm{C}$ and systolic blood pressure with p-value of 0.030 , and relative risk (RR) of 1.431 at a $95 \%$ confidence level (CI: 0.983 2.275). The relationship between the levels of serum cystatin $\mathrm{C}$ and diastolic blood pressure was found at $\mathrm{p}$-value of 0.000 and relative risk (RR) of 1.290 with a $95 \%$ confidence level (CI: 0.515-12.076). Since the p-value was less than 0.05 , it could be concluded that there was a significant relationship between the levels of serum cystatin $\mathrm{C}$ and systolic and diastolic blood pressure.

\section{DISCUSSION}

In this study, the relationship between serum cystatin $\mathrm{C}$ levels and systolic blood pressure was significant $(\mathrm{p}=0.030$, $\mathrm{RR}=1.431,95 \%$ CI: 0.983-2.275) whereas the relationship between the levels of serum cystatin $\mathrm{C}$ and diastolic blood pressure was also significant $(\mathrm{p}=0.000, \mathrm{RR}=1.290,95 \% \mathrm{CI}$ : $0.515-12.076)$. This suggests an association or effect of cystatin $\mathrm{C}$ levels on systolic and diastolic blood pressure in the elderly population with normal renal function.

This result is in line with the study conducted by Kestenbaum et al. (2008) found that each $15 \mathrm{nmol} / \mathrm{L}(0.2$ $\mathrm{mg} / \mathrm{L})$ rise in the levels of cystatin $\mathrm{C}$ was able to increase the risk of hypertension incidence by $15 \%$ [13]. A study by Salgado et al. (2013) supported that cystatin C could be used as a screening markers both to detect mild deterioration in kidney function and to prevent the risk of cardiovascular complications in hypertensive subjects with normal renal function [14].

Another study that supports this result showing that increased systolic blood pressure of $1.19 \pm 0.55 \mathrm{mmHg}$ led to elevated levels of serum cystatin $\mathrm{C}$ of $0.4 \mathrm{mg} / \mathrm{L}$ when the kidney was in a normal condition [15]. The previous study by Prats et al. (2010) also described that patients with high levels of cystatin $\mathrm{C}$ correlated with high prevalence of cardiac hypertrophy, which contrarily indicated no correlation with serum creatinine or GFR estimation in patients. Consequently, the results of this study correspond to those of the previous study [16] though they were 
conducted on adult patients instead of specifically on elderly patients.

According to the National Kidney Foundation (2016), some references stated that at the age of over 50 years old, the levels of serum cystatin $\mathrm{C}$ may be higher, which can therefore become one of the factors affecting the results of the levels of cystatin C measurement in this study. In the elderly, the changes occur not only to the blood vessels but also to renal function that can decline due to the cell generation process [17]. Wang et al. (2015) showed in their study that the serum cystatin $\mathrm{C}$ levels of elderly patients with coronary artery disease and hypertension were closely related to the levels of systolic and diastolic blood pressure and degree of coronary arteries occlusion. Serum cystatin $\mathrm{C}$ may become a predictor of disease severity in hypertensive elderly patients with coronary heart disease [18].

Similar findings supporting these results come from research by Sur et al. (2015) in India which observed that cystatin $\mathrm{C}$ had a significant positive correlation with systolic blood pressure in stage I and stage II hypertensive patients. However, their study found that cystatin $\mathrm{C}$ did not show a significant correlation with diastolic blood pressure. Since systolic blood pressure is significantly associated with kidney function at various levels of cystatin $\mathrm{C}$, even in subjects with normal renal function, this may provide an important association in the diagnosis of deteriorated kidney function at an early stage [19]. Liu et al. (2014) showed that the greater the metabolic scores, the higher serum cystatin $\mathrm{C}$ levels in metabolic syndrome patients. Serum cystatin $C$ levels are significantly associated with blood pressure, body mass index, waist circumference, waist-hip ratio, waist-height ratio, triglyceride, and fasting plasma glucose, but not correlated with LDL cholesterol levels, and negatively correlated with HDL-cholesterol levels [20].

This study has a limitation in that the study samples selected were only limited to the elderly participants at an Integrated Health Service Post (Posyandu) in Kotagede Yogyakarta, making it unable to reflect the actual population. In addition, the confounding factors (comorbidity disease such as hypertiroidism, rheumatoroid disease, autoimmune disease) that could affect the levels of cystatin $\mathrm{C}$ in the study samples had not been fully controlled.

\section{CONCLUSIONS}

The levels of serum cystatin $\mathrm{C}$ had significant effects on the increase in both systolic and diastolic blood pressure in the elderly with normal renal function.

\section{REFERENCES}

[1] Badan Penelitian dan Pengembangan Kesehatan, "Riset Kesehatan Dasar (RISKESDAS) 2013," Lap. Nas. 2013, 2013, doi: 1 Desember 2013.

[2] Aru W. Sudoyo. dkk, Buku Ajar Ilmu Penyakit Dalam Jilid III Edisi VI. 2014.
[3] B. Darmojo, Buku Ajar Geriatri (Ilmu Kesehatan Usia Lanjut). 2014.

[4] M. T. Crim et al., "National surveillance definitions for hypertension prevalence and control among adults," Circ. Cardiovasc. Qual. Outcomes, 2012, doi: 10.1161/CIRCOUTCOMES.111.963439.

[5] J. E. Hall et al., "Hypertension: Physiology and pathophysiology," Compr. Physiol., vol. 2, no. 4, pp. 2393-2442, 2012, doi: 10.1002/cphy.c110058.

[6] A. Yannoutsos, B. I. Levy, M. E. Sarefar, G. Slama, and J. Blacher, "Pathophysiology of hypertension: Interactions between macro and microvascular alterations through endothelial dysfunction," Journal of Hypertension. 2014, doi: 10.1097/HJH.0000000000000021.

[7] R. Garcia-Carretero et al., "Cystatin C as a predictor of cardiovascular outcomes in a hypertensive population," J. Hum. Hypertens., 2017, doi: 10.1038/jhh.2017.68.

[8] M. G. Shlipak, M. D. Mattes, and C. A. Peralta, "Update on cystatin C: Incorporation into clinical practice," American Journal of Kidney Diseases. 2013, doi: 10.1053/j.ajkd.2013.03.027.

[9] R. Zhao, Y. Li, and W. Dai, "Serum cystatin C and the risk of coronary heart disease in ethnic Chinese patients with normal renal function," Lab. Med., 2016, doi: 10.1093/labmed/lmv004.

[10] D. Tientcheu et al., "Target organ complications and cardiovascular events associated with masked hypertension and white-coat hypertension: Analysis from the Dallas Heart Study," J. Am. Coll. Cardiol., 2015, doi: 10.1016/j.jacc.2015.09.007.

[11] M. Dupont, Y. Wu, S. L. Hazen, and W. H. Wilson Tang, "Cystatin C identifies patients with stable chronic heart failure at increased risk for adverse cardiovascular events," Circ. Hear. Fail., 2012, doi: 10.1161/CIRCHEARTFAILURE.112.966960.

[12] S. W. van der Laan et al., "Cystatin C and Cardiovascular Disease: A Mendelian Randomization Study," J. Am. Coll. Cardiol., 2016, doi: 10.1016/j.jacc.2016.05.092.

[13] B. Kestenbaum et al., "Differences in kidney function and incident hypertension: The multi-ethnic study of atherosclerosis," Ann. Intern. Med., 2008, doi: 10.7326/0003-4819-148-7-200804010-00006.

[14] J. Victor Salgado et al., "Cystatin C, kidney function, and cardiovascular risk factors in primary hypertension," Rev. da Assoc. Médica Bras. (English Ed., 2013, doi: 10.1016/s2255-4823(13)70425-9.

[15] C. A. Peralta, M. A. Whooley, J. H. Ix, and M. G. Shlipak, "Kidney Function and Systolic Blood Pressure New Insights From Cystatin C: Data from the Heart and Soul Study," Am. J. Hypertens., 2006, doi: 10.1016/j.amjhyper.2006.02.007. 
[16] M. Prats et al., "Cystatin C and cardiac hypertrophy in primary hypertension," Blood Press., 2010, doi: 10.3109/08037050903416386.

[17] National Kidney Foundation, "The Kidney Disease Outcomes Quality Initiative (K/DOQI) of the National Kidney Foundation (NKF)," Natl. Kidney Found., 2016.

[18] Y. Wang, X. Su, W. Zhang, W. Yang, Y. Wang, and $\mathrm{Y}$. He, "Correlation between serum cystatin $\mathrm{C}$ level and elderly hypertensive patients combined coronary heart disease,” Int. J. Clin. Exp. Med., 2015.

[19] A. Sur, "Study of Relationship between Kidney Function and Systolic Blood Pressure: New Insights from Cystatin C," Biochem. Anal. Biochem., 2015, doi: 10.4172/2161-1009.1000226.

[20] P. Liu, S. Sui, D. Xu, X. Xing, and C. Liu, "Clinical analysis of the relationship between cystatin $\mathrm{C}$ and metabolic syndrome in the elderly," Rev. Port. Cardiol., 2014, doi: 10.1016/j.repc.2014.01.019. 